\title{
МИСТЕЦЬКА ОСВІТА: ВЕКТОРИ РЕФОРМУВАННЯ
}

\author{
За матеріалами обговорення проєкту Державного стандарту базової середньої \\ освіти в експертному середовищі 20 лютого 2020 р., м. Київ, Україна
}

https://doi.org/10.37472/2707-305X-2020-2-1-3-3

\section{KOMAРОВСЬКА}

\section{Оксана Анатоліївна}

доктор педагогічних наук, музикознавець, завідувачка лабораторії естетичного виховання та мистецької освіти Iнституту проблем виховання Національної академії педагогічних наук України, член Національної спілки театральних діячів України, м. Київ, Україна

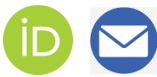

\section{ПРОСІHА}

\section{Ольга Володимирівна} кандидат педагогічних наук, завідувачка кафедри фрілософрії $i$ освіти дорослих Центрального інституту післядипломної освіти Державного закладу вищої освіти «Університет менеджменту освіти», Національна академія педагогічних наук України, м. Київ, Україна

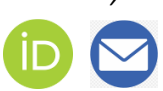

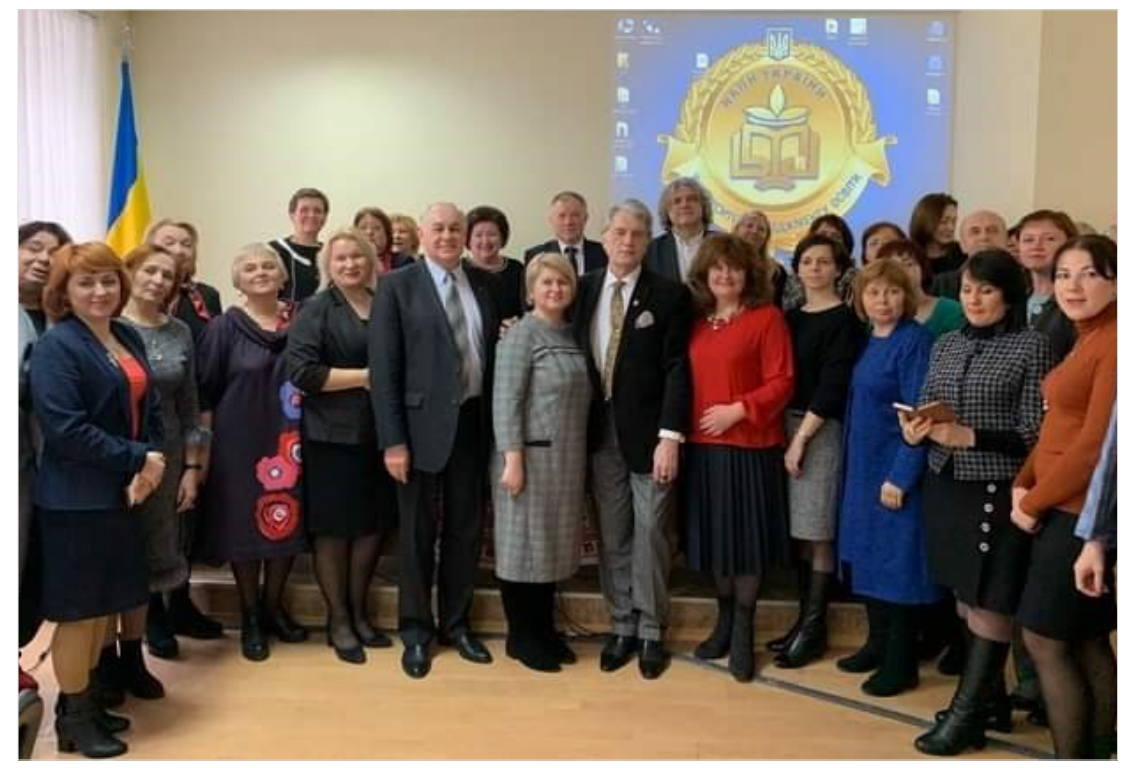

Анотація. Процес реформування освіти безпосередньо стосується мистецької освіти, яка виокремлена в самостійну галузь і об'єднує освоєння здобувачами освіти кількох предметних сфер (за видами мистецтва), що закріплено в кониептуальних документах Нової української школи. Представлено ключові тези колективної доповідіпрезентації розробників документа на етапі підготовки до широкого громадського обговорення в експертному середовищі. До складу робочої групи увійшли: О.М. Івасюк, канд. філол. наук, доцент, експерт Команди підтримки реформ МОН України; О.А. Комаровська, докт. пед. наук, музикознавець, завідувачка лабораторії естетичного виховання та мистецької освіти Інституту проблем виховання НАПН України, член Національної спілки театральних діячів України; О.В. Гайдамака, канд. пед. наук, старший науковий співробітник Інституту модернізації змісту освіти; О.В. Просіна, канд. пед. наук, завідувачка кафедри фрілософії і освіти дорослих Центрального інституту післядипломної освіти ДЗВО «Університет менеджменту освіти»; О.В. Волошенюк, кінознавець, науковий співробітник відділу екранно-сценічних мистецтв та культурології Інституту мистецтвознавства, фольклористики та етнології ім. М.Т. Рильського НАН України, менеджер медіаосвітніх програм Академії української преси.

Ключові слова: проєкт Державного стандарту загальної середньої освіти; мистецька освітня галузь; компетентнісний потенціал мистецької освіти; ядро знань; змістові лінії мистецької освіти; вимоги до обов'язкових результатів навчання, художнє пізнання.

Специфіка мистецтва як об'єкта пізнання людини, його впливу на формування ї̈ як особистості зумовлюють цілі мистецької освітньої галузі, а саме її спрямування на:

- формування і розвиток цілісної особистості у процесі художнього пізнання, що логічно випливає із художньо-образної 
природи мистецтва, зокрема 3 його здатності втілювати будь-які теми і сюжети, що цікавлять людину, крізь призму їх індивідуалізованого проживання і митцем, і реципієнтом як співтворцем, а також із притаманної мистецтву опори на емоційну сферу людини, що зумовлює утворення ії художніх цінностей, а далі - життєвих цінностей через мистецтво;

- утвердження здатності національної самоідентифікації в згармонізованому міжкультурному діалозі; ця вимога особливо загострюється нині у зв'язку з суперечливими процесами, зумовленими, зокрема, політичними подіями; аксіоматичним є посилення виховної функції мистецької освіти щодо формування людини патріота своєї держави; мистецтво в цьому аспекті має необмежені можливості впливати на емоційно-почуттєву сферу, оскільки «оперує» творами як концентратом емоційної енергії народу, енергетичним зарядом, утіленим авторами в художніх образах. Звернення до національного мистецтва всіх видів, жанрів, стилів, епох дає людині можливість через естетичні переживання ідентифікувати себе як представника нації і одночасно - відчути себе людиною культури, осмислити значущість і непересічність «свого» у світовому мистецькому просторі, а заразом усвідомити величезне художнє розмаїття світу з повагою до нього;

- набуття здобувачами освіти ключових компетентностей, окреслених, зокрема, в Законі України «Про освіту», які мають цілеспрямовано простежуватись у реалізації завдань кожної освітньої галузі, але, зрозуміло, в кожній галузі мають свою специфіку і при тому є необхідними кожній особистості для самореалізації у будь-якій сфері життєтворчості;

- формування комплексу мистецьких предметних (в широкому розумінні) компетентностей, завдяки оперуванню якими власне й уможливлюється досягнення попередньої позиції.

Наголосимо: разом усе зазначене може значною мірою втратити сенс, якщо стрижневим орієнтиром, своєрідним маяком мистецької освіти, не стане життєвий і професійний успіх учня, пов'язаний з його особистісною мобільністю, інновативним мисленням, мотивацією саморозвиватися, тобто з розкриттям креативного потенціалу кожної дитини, що найвиразніше відображається саме через пізнання різних видів мистецтва.

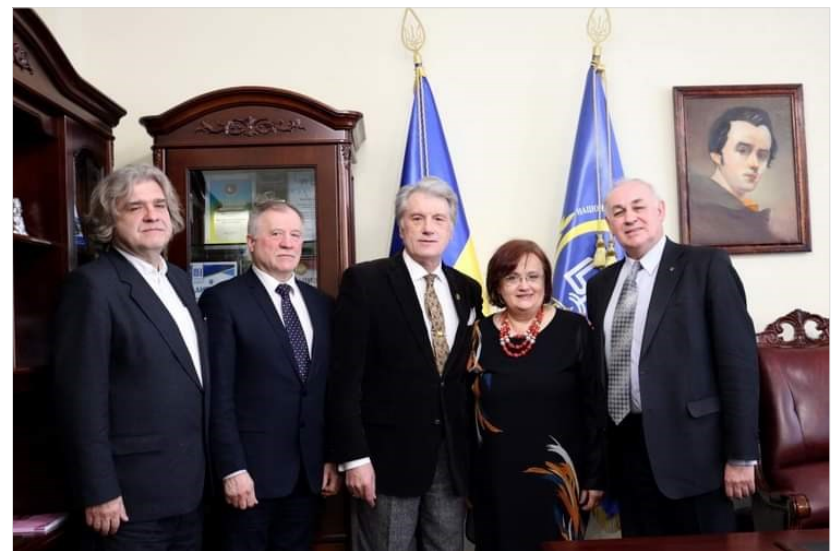

Надзвичайно важливою позицією щодо цілей мистецької освітньої галузі $€$ актуалізований «вихід за межі» мистецтва, тобто від формування знань і умінь, що стосуються різних видів мистецької діяльності (понятійного тезаурусу, сприймання творів, оволодіння практичними прийомами творення тощо), до сфери культуротворення, народження відчуття причетності до культурних процесів в Україні і пробудження потреби на них впливати, здатності розпізнавати квазіхудожнє тощо. Тобто йдеться про особистість як суб'єкт культури через мистецьку освіту.

Орієнтир мистецької освітньої галузі на формування цілісної особистості, що конкретизовано вище, логічно реалізується у чіткому окресленні місця пізнання мистецтва здобувачами освіти для набуття комплексу ключових компетентностей (Закон України «Про освіту», 2017; Гриневич та ін., 2016).

3 огляду на те, що узагальнено поняття компетентності акцентує, передусім, певні уміння особистості, які вона на підставі сформованого ставлення здатна і вмотивована вводити в дію у різноманітних життєвих/професійних обставинах, у стандарті як уніфікованому документі сутність кожної компетентності тому і конкретизується через позиції «уміння» і «ставлення», що формуються в учнів упродовж опанування усіх навчальних дисциплін через реалізацію змісту / вимог усіх освітніх галузей.

Звернімо увагу: якщо розглядати весь комплекс ключових компетентностей як певну систему, то з позиції мистецької освітньої галузі системоутворювальним елементом, безумовно, постає компетентність культурна. Доречно навести думку Ю. Богуцького щодо ролі мистецької освіти «як сфери культурного самостворення людської особистості», що виконує функцію своєрідного «лакмусового папірця», переконливого індикатора... «онтологічної кореляції» 


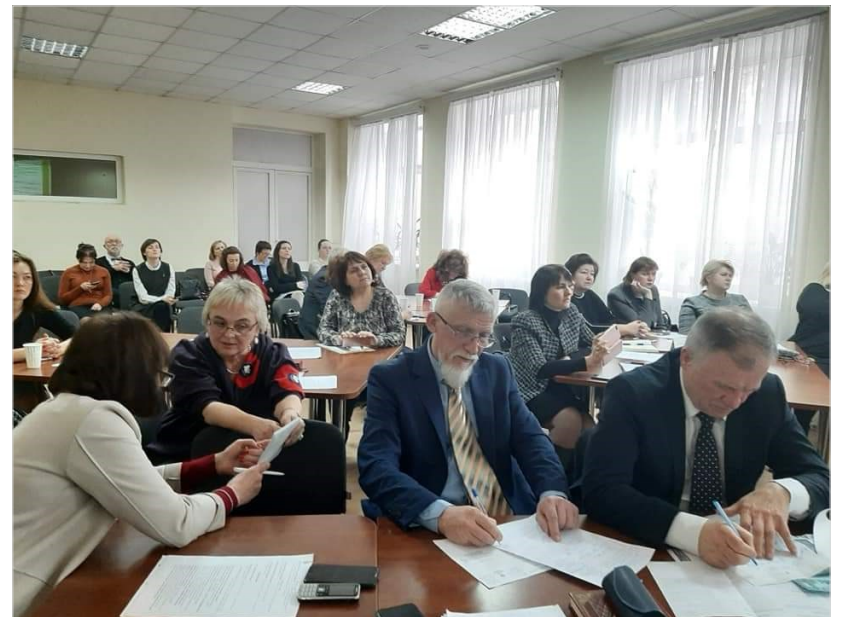

духовних цінностей суспільства» (Богуцький, 2008, с. 157). Зрозуміло, що:

- по-перше, поняття «культура» $є$ ширшим, ніж «мистецтво», втім саме художнє пізнання становить фундамент формування культурної компетентності через унікальну властивість мистецтва художньо образно перетворювати життя у його багатогранності;

- по-друге, зміст культурної компетентності як широкого втілення сутності поняття «культура» вбирає в себе зміст решти ключових компетентностей. Отже, очевидною $є$ унікальна здатність художнього пізнання впливати на формування решти ключових компетентностей, а також через емоційно-почуттєву сферу, зокрема художню емпатію і рефлексію - розвивати особистість цілісно.

Якщо ж конкретизувати зміст культурної компетентності у контексті мистецької освітньої галузі, то, безумовно, ії набуття передбачає засвоєння особистістю комплексу вмінь, наприклад, критично оцінювати художні явища, орієнтуватися у культурному розмаїтті та проявах діалогу між культурами, зокрема в мистецькій площині, а також здатності комунікувати з іншими суб'єктами мистецького діалогу, продукувати ідеї та реалізовувати їх у сфері мистецтва тощо. Немає сумнівів у тому, що для мистецької освіти на перший план має бути винесено питання саморозвитку, передусім, емоційно-почуттєвої сфери через сприймання мистецтва та художню творчість. Опанування подібними уміннями - через перманентну активацію переживання творів і подій з подальшим осмисленням - формує комплекс «ставлень». Серед «ставлень» особливо виокремлюємо прийняття цінностей власне художніх, а також загальнолюдських, оскільки «транслятором» таких цінностей $є$ справжній витвір мистецтва.

Сформована через мистецьку освітню галузь культурна компетентність включає і відчуття гордості за надбання українського мистецтва разом із повагою до мистецьких надбань інших культур, що становить фундамент для усвідомлення власної ідентичності у світовому контексті. Важливим вбачається загалом розуміння важливості естетичних чинників у повсякденному житті, що впливає 3 «естетизації мислення» (за висловом М. Мамардашвілі).

Компетентнісний потенціал мистецької освітньої галузі визначався розробниками із двох взаємопов' язаних вихідних позицій, а саме:

1) в який спосіб навчання мистецтва забезпечує формування решти ключових компетентностей;

2) на чому зі змісту кожної ключової компетентності доцільно акцентувати для повноцінного занурення у художні твори.

Перетин цих позицій і дає можливість учням наблизитись до усвідомлення системності Всесвіту, що становитиме фундамент для окресленої в меті мистецької освітньої галузі цілісності особистості, яка буде мобільною у змінюваному світі, володітиме інноваційним мисленням, внутрішньою потребою самовдосконалення, емоційним інтелектом, критичним мисленням, а основне - імунітетом до антигуманного і особистісно руйнівного в різних його проявах.

Так передбачено зустрічні вектори в реалізації компетентнісного потенціалу мистецької освітньої галузі, які надалі враховуватимуться при складанні типових освітніх програм, написанні підручників, розробленні методик тощо, а саме:

- залучення у процесі навчання мистецтва досвіду з інших освітніх галузей (сфер знання) для поглиблення емоційності осягнення художніх творів;

- вихід через осягнення художнього твору в розуміння довкілля, людських взаємин, що дає змогу пережити будь-яке знання з інших галузей саме на основі твору мистецтва, а отже, повноцінніше оволодіти ним, розвинути здібності у сферах цих галузей.

Наприклад, формування математичної компетентності передбачає, зокрема, не лише уміння здійснювати певні розрахунки (пропорцій, об'ємів, перспективи, ритму тощо), а й пояснювати художню виразність творів і власні враження 
від них, за доцільністю звертаючись до математичних понять. І навпаки: за допомогою мистецтва можна актуалізувати для себе математичні категорії, «відчуваючи» їх в новому образному значенні. Розвиваючи через опанування різних видів мистецтва художньо-образне мислення, учень поглиблює здатність емоційно проживати математичні знання. У такий спосіб, через пізнання мистецтва народжується усвідомлення взаємозв'язку математики і мистецтва як універсальних, хоча і дещо протилежних мов та розуміння впливу художнього пізнання на розвиток математичних здібностей та умінь.

Формування через мистецьку освітню галузь компетентності в галузі природничих наук, техніки і технологій так само передбачає не лише наявність в учнів умінь використовувати для художньої творчості різноманітні природні матеріали або ж різноманітні технічні прилади і технології, знання 3 акустики, хімії, оптики, фізики, астрономії тощо, а й уміння досліджувати об'єкти довкілля, щоб використовувати результати спостережень для створення художніх образів. Такі спостереження стосуються, наприклад, художнього узагальнення/типізації зовнішніх проявів характеру людини в ї̈ міміці, поставі, ході, жестикулюванні, характерному мовленні, що істотно для акторської, живописної, літературної творчості тощо. Дослідження різноманітних тембрів звуків і способів звуковидобування, зокрема в повсякденні, можуть знадобитися в образно-виражальній системі засобів музичного твору. Так формується ставлення до світу як об'єкта для художньо-образної інтерпретації. Тобто емоційність ставлення до довкілля, що народжується завдяки пізнанню мистецтва, у відповідь поглиблює прагнення емоційноестетичного пізнання цього довкілля і відчуття зв'язку з ним.

Подібні зв'язки вкладаються у зміст кожної із ключових компетентностей з різними видами мистецької діяльності. Але важливо наголосити на доцільності залучення цих зв'язків у освітній процес і принциповому орієнтуванні мистецької освітньої галузі на їі стрижневі категорії, а саме на першість художнього образу як одиниці мислення у процесі художнього пізнання, що є інтегральним і багатоскладовим за сутністю (Komarovska, 2019).

Окрему увагу слід звернути на змістові лінії мистецької освітньої галузі. Зазначимо, що змістові лінії не позначаються у такому документі як освітній стандарт, утім презентований проєкт документа вибудовується за наступністю із Державним стандартом початкової освіти (постанова Кабінету Міністрів України від 21 лютого 2018 р. № 87), на підставі чого розроблено типові освітні програми, в яких ці змістові лінії зафіксовані. Крім того, на них зорієнтовано зміст усіх складників документа, зокрема вони враховані в структуруванні «ядра знань», вимогах до результатів навчання здобувачів освіти тощо.

Такими змістовими лініями є: «художньопрактична творчість»; «сприймання та інтерпретація творів мистецтва»; «комунікація через мистецтво». Отже, справжнім змістом мистецької освіти стає не сукупність певної інформації з різних видів, жанрів або стилів мистецтва, конкретних творів і творчості митців, яку учень має засвоїти у вигляді багажу знань, а способи освоєння мистецтва учнем, він сам, його внутрішній світ, ставлення до світу і до себе через художнє пізнання. У результаті опанування мистецької освіти такими способами, учень оволодіває знаннями.

Так, знання здобуваються особистістю під час сприймання та аналізу творів, коли формується ціннісне ставлення, яке неможливо висловити і сформулювати, якщо не оперувати понятійним апаратом. Відповідні знання «визрівають» у процесі опанування способами і прийомами практичного творення й рефлексії результатів творчості. Зрозуміло, що художня комунікація також неможлива без доцільного оперування знаннями, до застосування яких особистість уже вмотивована, інакше комунікація не відбудеться.

Саме з цього погляду визначено зміст такого структурного складника проєкту мистецької освітньої галузі, як «ядро знань», що охоплює власне понятійний апарат мистецтва (поняття, що набуваються у процесі сприймання і необхідні для здійснення аналізу творів), термінологія, необхідна під час художньо-творчої діяльності (відображає практично-творчий компонент опанування мистецтва), комунікація з мистецтвом (знання, що спрямовують особистість на суб'єктність у різних іпостасях художнього діалогу).

Зазначимо і такий істотний момент: кожен із структурних складників «ядра знань», пов'язаний із способами освоєння особистістю мистецтва і світу через мистецтво, неминуче містить комплекс «само» (самопізнання, самовираження, 
самореалізація, саморозвиток тощо) через різні види мистецької діяльності. Відповідно до цього, в Додатку виокремлено групи умінь, які передбачено сформувати в учнів (розділ «Вимоги до обов'язкових результатів навчання здобувачів освіти з мистецької освітньої галузі»), а саме:

1) пізнання різних видів мистецтва, інтерпретація художніх образів, досвід емоційних переживань, ціннісне ставлення до мистецтва;

2) художньо-образне, асоціативне мислення під час творчої діяльності в різних видах мистецтва;

3) пізнання себе через взаємодію з різноманітними мистецькими об'єктами; розвиток емоційного інтелекту;

4) використання інформаційного середовища у власній творчості та художній комунікації.

Розробляючи вимоги до обов'язкових результатів навчання здобувачів освіти з мистецької освітньої галузі, робоча група керувалася тим, що вплив мистецтва на особистість $€$ унікальним, оскільки воно здатне комплексно діяти на різні сфери психічної діяльності, формуючи в особистості почуття, розум, волю. Головною метою педагогічного керування таким впливом $є$ не збільшення знань про особливості об'єктивного світу, хоча пізнавальна функція й притаманна мистецтву, а насамперед емоційночуттєвий розвиток учнів. Тому так важливо знаходити для вимірювання обов'язкових результатів критерії, які допоможуть зосередитися саме на розвитку особистості під час взаємодії з мистецтвом, враховуючи, що мистецтво має специфічні виразні засоби і можливості впливу на особистість.

Серед наскрізних умінь, які виокремленні в Концепції Нової української школи, у рамках підготовки майбутніх педагогів мистецтва звертаємо увагу на вміння застосовувати емоційний інтелект. Адже традиційні підходи до викладання мистецьких дисциплін, зазвичай, не враховували важливість набуття емоційного інтелекту засобами мистецтва. Зокрема, хибною $\epsilon$ поширена думка практиків, що заняття мистецтвом неодмінно забезпечує розвиток емоційного інтелекту, тоді як насправді цей розвиток має здійснюватись цілеспрямовано протягом усього періоду навчання, причому із використанням відповідних методів.

Нині не виникає заперечень, що емоції - це необхідна складова для реалізації особистості в будь-якій професійній сфері: завойовувати

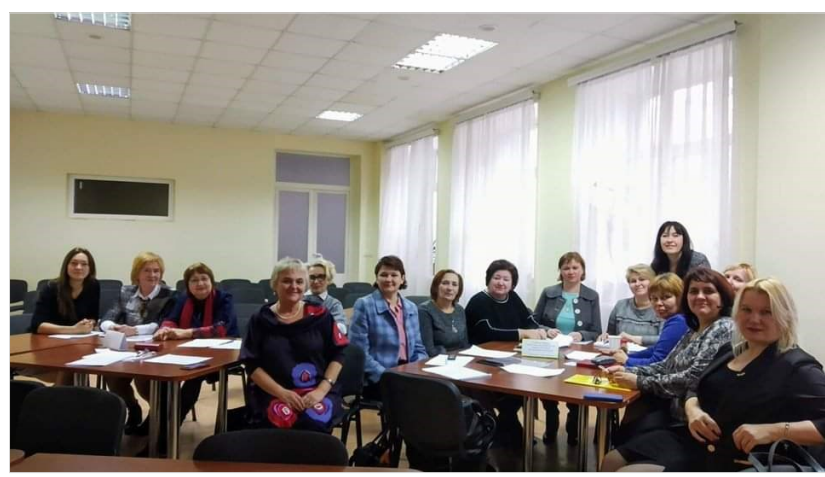

довіру; зміцнювати відносини; формувати бачення; концентрувати енергію; управляти людьми; знаходити компроміси; приймати непрості рішення і здобувати корисний досвід 3 невдач. Без щирих емоцій особистість не буде досягати успіху. Емоції потрібні як на фронтальному рівні - щоб встановлювати пріоритети, так і на зворотному зв'язку - щоб мотивувати і надихати людей. Під таким розвитком засобами мистецтва розуміємо навчання, спрямоване на розвиток емоційного інтелекту через сукупність методів і прийомів для формування умінь проводити спостереження й осмислювати емоційний стан власний та інших людей, розвиток навичок співпереживати емоційному стану інших та здійснювати управління і корекцію власних емоцій засобами мистецтва.

У Додатку до Державного стандарту обов'язкові результати за кожною групою умінь розкриваються через загальні результати, конкретні результати та орієнтири для оцінювання. Так, наприклад, для вимірювання групи вмінь: «Пізнання себе через взаємодію з різноманітними мистецькими об'єктами; розвиток емоційного інтелекту» пропонується виокремити на рівні загальних результатів такі аспекти: учень/учениця демонструє власні досягнення, регулює власний емоційний стан засобами мистецтва, оцінюе власні мистецькі здобутки, взаємодіє з іншими через мистецтво. Далі в конкретних результатах передбачена деталізація кожного пункту та наводяться орієнтири для подальшого оцінювання.

\section{СПИСОК ВИКОРИСТАНИХ ДЖЕРЕЛ}

Богуцький, Ю.П. (2008). Самоорганізація культури: онтологія, динаміка, перспективи : монографія. Інститут культурології АМУ. Київ: Веселка.

Волошенюк, О., Баликін, І., Волошенюк, О., Чорний, О., \& Федченко, О. (2019). Абетка візуальної грамотності. Київ: АУП, ЦВП.

Гайдамака, О.В., Комаровська, О.А. та ін. (2018). Мистецька освітня галузь. Початкова освіта 
Методичні рекомендації щодо використання в освітньому прочесі Типової освітньої програми для 1 класів закладів загальної середньої освіти; типова освітня програма для закладів загальної середньої освіти (колективу авторів під керівництвом О.Я. Савченко); методичні коментарі провідних науковців Інституту педагогіки НАПН України щодо впровадження ідей Нової української школи в початковій освіті; орієнтири для календарно-тематичного планування (1 клас НУШ) (с. 64-69). Київ: УОВЦ «Оріон».

Гриневич, Л., Елькін, О., Калашнікова, С., Коберник, І., Ковтунець, В., Макаренко, О., Малахова, О., Нанаєва, Т., Усатенко, Г., Хобзей, П., \& Шиян, Р. (2016). Нова українська школа. Концептуальні засади реформування середньої школи (М. Грищенко, заг. ред.). Міністерство освіти і науки України. https://mon.gov.ua/storage/app/ media/zagalna\%20serednya/nova-ukrainska-shkolacompressed.pdf
Закон України «Про освіту» (2017). Взято з https:// zakon.rada.gov.ua/laws/show/2145-19

Комаровська, О.А. (2018). Мистецькі досягнення учнів: що і як оцінюємо? Мистецтво та освіта, (4), 2-7. https://doi.org/10.32405/2308-8885-2018-4-2-7

Постанова Кабінету Міністрів України «Про затвердження Державного стандарту початкової освіти» від 21 лютого 2018 р. № 87 . https:// www.kmu.gov.ua/npas/pro-zatverdzhennyaderzhavnogo-standartu-pochatkovoyi-osviti

Просіна, О.В. (2018). Розвиток емоційного інтелекту як основа формування професійної компетентності майбутнього вчителя музики. Гірська школа Українських Kapnam, (18), 124-128.

Komarovska, O. (2019). Strategies of Contemporary General Arts Education. In O. Oleksiuk (Ed.), Individual Spirituality in Post-nonclassical Arts Education (pp. 319). Cambridge Scholars Publishing.

\section{ART EDUCATION: VECTORS OF REFORM \\ Based on the discussion among experts of the Draft State Standard for Basic Secondary Education, February 20, 2020, Kyiv, Ukraine}

\section{Oksana Komarovska}

DSc in Pedagogy, Musicologist, Head of the Laboratory of Aesthetic and Art Education, Institute of Problems on Education of the National Academy of Educational Sciences of Ukraine, Member of the National Union of Theatre Artists of Ukraine, Kyiv, Ukraine

Olga Prosina

PhD in Pedagogy, Head of the Department of Philosophy and Adult Education of the Central Institute of Postgraduate Education, State Higher Education Institution "University of Educational Management", National Academy of Educational Sciences of Ukraine, Kyiv, Ukraine

Abstract. The education reforming process is directly related to art education, which is separated into an independent field and integrates several subject areas (by art), which is fixed in the conceptual documents of the New Ukrainian School. Key statements of the collective report-presentation of the document developers are presented. Among the working group members were: O. Ivasiuk, PhD in Philology, Associate Professor, Expert of the Reform Support Team of the Ministry of Education and Science of Ukraine; O. Komarovska, DSc in Pedagogy, Musicologist, Head of the Laboratory of Aesthetic and Art Education at the Institute of Problems on Education of NAES of Ukraine, Member of the National Union of Theatre Artists of Ukraine; O. Gaidamaka, PhD in Pedagogy, Senior Researcher at the Institute of Education Content Modernization; O. Prosina, PhD in Pedagogy, Head of the Department of Philosophy and Adult Education at the SHEI "University of Educational Management"; O. Volosheniuk, Film Expert, Researcher of the Department of Screen and Performing Arts and Cultural Studies at the Rylsky Institute of Art Studies, Folklore and Ethnology of NAS of Ukraine, Manager for media educational programs at the Academy of Ukrainian Press.

Keywords: draft State Standard for Basic Secondary Education; art education; competent potential of art education; core of knowledge; content lines of art education; requirements for compulsory learning outcomes; artistic cognition. 